\title{
Biomass and Carbon Stored Estimated in the forest ecosystem of the Nova Canaã Farm (Porciúncula/RJ)
}

Global warming has become international concern, culminating with the ratification of the Kyoto Protocol which includes definitions and objectives of the sustainable development mechanisms and features that make it easier for the industrialized countries to jointly compensate for their polluting greenhouse gas emissions. Porciúncula is a city known for its agricultural development and the lack of characterization of ecosystems associated with the Atlantic Forest biome. Facing this chaotic scenario is Nova Canaã farm located in the Ribeirão da Perdição Environmental Preservation Area its forest ecosystem provides a series of environmental services such as carbon storage and $\mathrm{CO}_{2}$ sequestration. The team of researchers from OM Consultoria Ambiental performed the quantification of the biomass $\left(B_{\text {wood }}\right)$ of the bole which resulted in estimates of $398.4753 \mathrm{t}^{-h^{-1}}{ }^{-1}$ corresponding to $199.2377 \mathrm{tC}$. ha $\mathrm{A}^{-1}$. The estimates obtained for the forest ecosystem of the farm can be used as a reference for the establishment of forest restoration projects under the under the sustainable development mechanism established the Kyoto Protocol.

Keywords: Environmental Service; Atlantic Forest; Forest Inventory; Dendrometry; APA Ribeirão da Perdição.

\section{Biomassa e Estimativa do Carbono Estocado no ecossistema florestal da Fazenda Nova Canaã (Porciúncula/RJ)}

O aquecimento global tornou-se preocupação internacional, culminando com a ratificação do Protocolo de Quioto, onde constam as definições e os objetivos do mecanismos de desenvolvimento sustentável e possui procedimentos flexibilizadores, facilitando aos países industrializados compensar em conjunto suas emissões poluentes de gases do efeito estufa. Porciúncula é um município conhecido pelo desenvolvimento agropecuário e pela descaracterização dos ecossistemas associados ao bioma Mata Atlântica. Frente a este cenário caótico está à Fazenda Nova Canaã, localizada na área de Preservação Ambiental (APA) Ribeirão da Perdição, seu ecossistema florestal é prestador de uma série de serviços ambientais como o estoque de carbono e o sequestro de CO2. A equipe de pesquisadores da OM Consultoria Ambiental, realizou a quantificação da biomassa ( $B_{\text {madeira}}$ ) do fuste, que resultou em estimativas de 398,4753 t.ha ${ }^{-1}$, o que correspondeu a 199,2377 tC.ha ${ }^{-1}$. As estimativas obtidas para o ecossistema florestal da fazenda podem ser usadas como referência para o estabelecimento de projetos de restauração florestal, no âmbito do Mecanismo de Desenvolvimento Limpo, estabelecido no Protocolo de Quioto.

Palavras-chave: Serviço Ambiental; Mata Atlântica; Inventário Florestal; Dendrometria; APA Ribeirão da Perdição.

Reviewed anonymously in the process of blind peer.

Vilma da Conceição Lima dos Santos (ID) Universidade Federal do Rio de Janeiro, Brasil http://lattes.cnpq.br/2973750808372755 http://orcid.org/0000-0003-4628-4718 omconsultoriaambiental@gmail.com

Cleber Vinicius Vitorio da Silva (iD Universidade Federal Rural do Rio de Janeiro, Brasil http://lattes.cnpq.br/4275890458575782

http://orcid.org/0000-0001-8337-9615 heliumcorp@heliumcorp.com.br

Josimar Ribeiro de Almeida (iD)

Universidade do Estado do Rio de Janeiro, Brasil http://lattes.cnpq.br/3215586187698472

http://orcid.org/0000-0001-5993-0665 almeida@poli.ufri.br

\author{
Juan Carlos Resende de Moraes (iD \\ Universidade Federal Rural do Rio de Janeiro, Brasil \\ http://lattes.cnpq.br/2120256098910920 \\ http://orcid.org/0000-0002-8762-2798 \\ resendejcm@gmail.com \\ Acacio Geraldo de Carvalho (iD) \\ Universidade Federal Rural do Rio de Janeiro, Brasil \\ http://lattes.cnpq.br/6260575742015817 \\ http://orcid.org/0000-0002-0935-7773 \\ acacio@ufrri.br \\ Carlos Domingos da Silva (D) \\ Universidade Federal Rural do Rio de Janeiro, Brasil \\ http://lattes.cnpq.br/6460426372841261 \\ http://orcid.org/0000-0001-8976-3220 \\ cdambiental@gmail.com
}

Vanessa da Silva Brandão (iD

Universidade Federal Fluminense, Brasil http://lattes.cnpq.br/8694811494605508 http://orcid.org/0000-0002-1119-212X vsbrandao@id.uff.br

Fábio José Esper (iD

Universidade de São Paulo, Brasil http://lattes.cnpq.br/9665897262541310 http://orcid.org/0000-0003-2147-0100 fabio.esper@usp.br

Rodrigo Cavalcante Passos da Silva (it) Universidade Federal Rural do Rio de Janeiro, Brasil http://lattes.cnpq.br/6498737871994093 http://orcid.org/0000-0002-2792-0654 florestal.rpassos@gmail.com

\section{Referencing this:}

SANTOS, V. C. L.; SILVA, C. V. V.; ALMEIDA, J. R.; MORAES, J. C. R.; CARVALHO, A. G.; SILVA, C. D.; BRANDÃO, V. S.; ESPER, F. J.; SILVA, R. C. P.. Biomass and Carbon Stored Estimated in the forest ecosystem of the Nova Canaã Farm (Porciúncula/RJ). Naturae, v.2, n.1, p.1-15, 2020.

DOI: 10.6008/CBPC2674-6441.2020.001.0001 DOI: http://doi.org/10.6008/CBPC2674-6441.2020.001.0001 


\section{INTRODUCTION}

Approximately 54.4\% of Brazil's territory is occupied by forests (SILVA et al., 2018) and from this percentage, approximately $12.5 \%$ corresponds to the area of the Atlantic Rainforest Biome (SOS MATA ATLÂNTICA, 2015), stretching for 17 States of the federation, going from the state of Rio Grande do Sul to Rio Grande do Norte, ranging from the coastal regions, such as plateaus and hills of the interior.

In the state of Rio de Janeiro, the Atlantic Forest biome offers characteristic phytoecological formations constituted by forest ecosystems: Seasonal Semidecicual Forest and Dense Ombrophilous Forest. The latter features subdivisions in its phytophysiognomy, suffering variations according to the altitude range of relief where it is inserted. The divisions are: The Alluvial Lowlands, Submontane Forest, Montana and AltoMontana (SOS MATA ATLÂNTICA, 2015).

According to SOS Mata Atlântica (2015), in addition to this important set of forest ecosystems, the Atlantic Forest biome also encompasses other associated ecosystems. Such as mangroves, sandbanks, mixed forests (Araucária forest) and altitude fields.

Most of the territory of the Northwest Fluminense is located in the phytoecological region of Seasonal Semideciduous Forest. A small part contemplates the Dense Ombrophilous Forest further south of the region in the São Fidélis city, close to the Desengano State Park.

Soffiati Netto (2011) describes the eco-history of the devastation of seasonal forests in the northnorthwest of Rio de Janeiro, between the colonial and republican periods. It emphasizes how the forest was initially felled by logging, behind hardwood, for use in the sugarcane agro-industry. Then by extensive coffee farming and cattle breeding which was responsible for decimating over approximately a century and a half what initially seemed infinite to the first colonizers and travelers.

However, even facing an intense and historical process of deforestation, the Atlantic Forest biome has one of the largest biodiversity in the planet, with high concentrations of endemic species (BERGALLO et al., 2016) and a high level of degradation. Thus, it is possible to consider it as a hotspot, being the conservation of its natural resources of utmost importance to mankind.

The plants are autotrophicorganisms, they need of $\mathrm{CO}_{2}$ for the production of their food through the photosynthetic process, in woody plants the incorporation of a part of this carbon in the secondary xylem of plant is popularly known as wood (SILVA et al., 2017). There are methods that allow researchers to evaluate the concentration of carbon in woody plants, however in native forests these measurements are only estimated, for in a community there is not a single model of growth and morphotype, because it is a set of populations dependent on the ecological relationships (HENRY et al., 2011).

Carbon sequestration and storage is, among the many environmental services provided by forests, one of great importance. Especially in face of global warming's intensification (SILVA et al., 2017). The phenomenon mentioned above is cause by the increase of the concentration of greenhouse gases, especially carbon dioxide $\left(\mathrm{CO}_{2}\right)$, methane $\left(\mathrm{CH}_{4}\right)$ and nitrous oxide $\left(\mathrm{N}_{2} \mathrm{O}\right)$, from human emissions (SILVA et al., 2017).

In order to mitigate these impacts arising from the emission of greenhouse gases, the Kyoto Protocol 
was created, as countries held as their paramount goal the reduction of emissions of these gases in $5.0 \%$ during the period from 2008 to 2012, which corresponds to the first commitment period (SILVA et al., 2019). The Protocol officially came into effect in February 2005 and brought three innovative mechanisms to ensure flexibility: Emissions trading, Joint Implementation and Clean Development Mechanism (CDM), by which it is possible to obtain the Certified Emission Reductions (CERS), which are one of the types of carbon credits. It is noteworthy that among these three mechanisms of flexibilization, only the CDM allows the participation of developing countries like Brazil, representing, therefore, a way for the country's participation in the recent and innovative carbon credits market (TORRES et al., 2013).

Nova Canaã farm is located in the Ribeirão da Perdição environmental protection area, which has 6,141 ha, of which 85 springs are preserved. O Ribeirão da Perdição é importante contribuinte do Rio Carangola. The Ribeirão da Perdição environmental preservation area, located in the Ribeirão Caeté microwatershed which is classified by the Ministry of the Environment as a priority for conservation. Reinforcing its importance in the environmental context of the Northwest region of Rio de Janeiro state as well as in Porciúncula city.

Faced with the importance of Nova Canaã farm for the State of Rio de Janeiro and the need to preserve its ecosystem, the team of researchers from OM Consultoria Ambiental, carried out this work, which aimed to quantify biomass in $\mathrm{m}^{3}$ through the installation of 16 plots (SU) of $500 \mathrm{~m}^{2}$ arranged systematically in a forest fragment of $440.000 \mathrm{~m}^{2}$ encompassing a sampling area of $8.000 \mathrm{~m}^{2}$, with the purpose of estimating the concentration of carbon in tC.ha-1 which is concentrated by the forest ecosystem of the farm.

\section{MATERIALS AND METHODS}

\section{Characterization of the study área}

The forest fragment is located in the area of influence of Fazenda Nova Canaã (Figure 1) in the environmental preservation area Ribeirão da Perdição. According to the Biosphere Reserve, the farm is inserted in the area of mosaics of Atlantic Forest corridors, one of the 84 areas destined to the conservation of this biome for the Porciúncula city. Most of its vegetation cover is made up of secondary stage forests and pastures. The city Porciúncula, is part of the phytophysionomic domain semideciduous seasonal forest has a mosaic of degraded and impacted forest physiognomies typical of areas with a history of agricultural and livestock activities.

Porciúncula has a tropical climate, with much more rainfall in summer than in winter. The climate is classified as Aw according to Köppen and Geiger. The average temperature in Porciúncula is $22.4^{\circ} \mathrm{C}$. The average annual rainfall is $1188 \mathrm{~mm}$. The driest month is July which has $12 \mathrm{~mm}$ of rainfal. The greatest amount of precipitation occurs in december with an average of $225 \mathrm{~mm}$. The warmest month of the year is february with an average temperature of $25.4^{\circ} \mathrm{C}$. with the lowest average temperature of the year, July has an average temperature of $18.7^{\circ} \mathrm{C}$.

The Nova Canaã farm is located in the Ribeirão Caeté microwatershed. Categorized as a priority, this 
due to the large presence of forest fragments and ecological corridors. Its conservation is important for the maintenance of fauna and flora, the scenic landscape and the dense network of water bodies. Importantly, protection is essential for maintaining the local and regional water balance, in addition to the environmental quality of the water bodies.

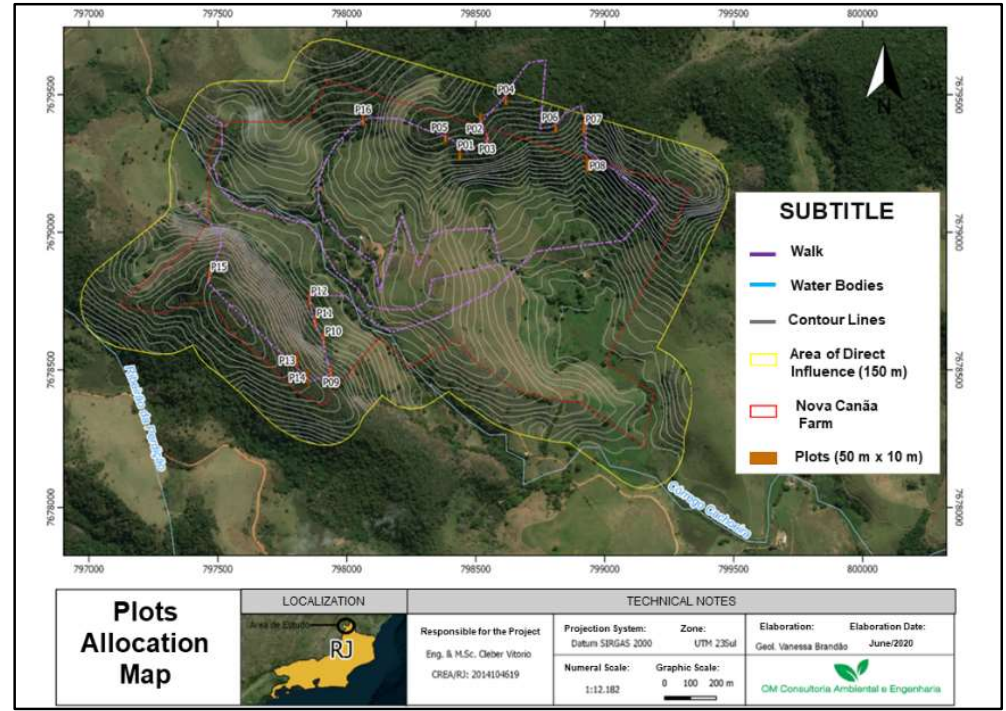

Figure 1: Nova Canaã farm area and design of sample units in the study area.

The study area is inserted in the domain of denudational units in crystalline rocks, dominated by dissected hills and low hills and reach quotas of a maximum of $992 \mathrm{~m}$. The study area is marked by the presence of hills with convex-concave geometry, frankly dissected. It is characterized by a lively relief with slopes of medium to high gradients and rounded to sharp tops. Moderate to high drainage density with subdendritic trellis pattern. Due to its morphology, the present relief is frequently affected by laminar erosion processes and sporadic occurrence of accelerated linear erosion processes. The predominant soils in the study area are: dystrophic red-yellow latosol and eutrophic red-yellow argisols.

\section{Sample Design and Analysis}

From 17 april until 24 april 2020, 16 quadratic sampling units $(10 \mathrm{~m} \times 50 \mathrm{~m})$ were demarcated in the area of the venture, totaling $8.000 \mathrm{~m}^{2}$ of sample area (Figure 1) the fragment studied has a total area of $440.000 \mathrm{~m}^{2}$, the field team catalogued all the botanical species existing in the quadratic plots of $500 \mathrm{~m}^{2}$, theymade these plots with tape and string. Within each quadratic plot they were collected arboreal species with CAP greater than or equal to $5 \mathrm{~cm}$, and estimated the height of sampled individuals. The quadrats were marked with striped tape. The vertex closest to the access to the sampling unit was georeferenced using a GPS with an accuracy of 3 meters under vegetation cover. The individuals were collected and catalogued in the herbarium of the laboratory of forage plants of UFRJ at the zootechnical institute and stored at the Laboratory of Environmental Mapping of UFRRJ (LAMAGEDENASA).

The simple random sampling is the fundamental process of selection from which to derive all other sampling procedures, aiming to increase the accuracy of estimates and to reduce the costs of the survey (RIBEIRO et al., 2009). The simple random sampling is the best method for presentation of the theory of 
sampling, because it allows estimating the sampling error. The selection of each sampling unit must be free of any choice and totally independent from the selection of the other sample units. The equation for the calculation of the sample sufficiency in simple random sampling is shown below (HUSCH et al., 1982) (Equation 1).

$$
n=N \times S^{2} \times t^{2} /\left(N \times\left(E x x^{-}\right)^{2}+S^{2} \times t^{2}\right.
$$

Where: $\mathbf{n}=$ number of parcels to be raised; $\mathbf{N}=$ total number of samples possible in the area; $\mathbf{t}=$ value of probability distribution ( $\mathrm{t}_{0.5}$, with $\mathrm{n}-1 \mathrm{GL}$ ); $\mathbf{S}^{\mathbf{2}}=$ variance of the parameter evaluated; $\mathbf{x}^{-}=$average $\mathbf{E}=$ Error $(10 \%)$ and $\mathbf{X}=$ Average of the parameter evaluated. The following are defined the symbols to identify the variables of the Community: the sample sufficiency was calculated on the basis of the parameter biomass $\left(\mathrm{m}^{3}\right)$, in view of the interest of the evaluation of the quantification of biomass in $\mathrm{m}^{3}$ and quantification of carbon stored in the tC.ha-1 of plants with secondary xylem and CAP above or equal to $5 \mathrm{~cm}$.

For the analysis of total biomass by species and botanical family we used the volumetric equation of CETEC (1995) which is used by other authors (RIBEIRO et al., 2009), Atlantic Forest vegetation (Equation 2):

$$
\mathrm{Vt}=0.00007423 \times \mathrm{DAP}^{1.707348} \times \mathrm{Ht}^{1.16873}
$$

Where:

$\mathbf{V t}=$ total volume of the bole;

DAP $=1.30 \mathrm{~m}$ above the ground;

$\mathbf{H t}=$ total height of each stem.

The estimate of the bole biomass was performed using the non-destructive method, depending on the impossibility of using the destructive method, due to restrictions of legal orders and operational. Thus, it was evaluated only the biomass of the stem and not other forest compartments, such as branches, leaves, bark and lianas.

The indirect method for quantification of biomass is based on the use of empirical relationships between biomass and other variables in the tree (DBH, total height etc.) (CETEC, 1995), these relations expressed by means of statistical models (SILVA et al., 2017). One needs to be cautious with its implementation, in order to avoid significant error in the calculation of biomass: a careful analysis of the situations of field (ex. hollow trees) and the sample is representative of the area (SILVA et al., 2019).

This method is often considered a more accurate alternative than the direct method, since in the latter, the information obtained usually come from parcels of small size, in a small number and selected intentionally, usually in areas that are more representative of the whole (BROWN et al., 1989). Such conduct could introduce errors of biased estimates, which may lead to over- or underestimation of the average biomass of the forest evaluated.

Considering the use of non-destructive method, we performed the selection of species with secondary xylem in the area (CETEC, 1995). Then, we obtained the values of basic density for each lignified species selected, based on existing studies (LORENZI, 2014; IBAMA, 2016). To determine the basic density of species not identified (Indet), we collected bodies of evidence, using a Pressler probe. The collections were 
always carried out in the morning, in order to avoid possible variations of the values of which could be caused by changes in water potential and perspiration after noon and the samples were stored individually in a plastic bag sealed until laboratory measurements. Synthesized the methodology for determining the basic density of the wood in the lab, as it is instructed in the norm ABNT NBR 11941 NBR11941, as for deceased individuals, we used an average value of the bodies of evidence sampled.

The basic density values obtained, already converted into Ton.m-3, it was calculated the average basic density (d) of all the mature forest, weighted by the value of coverage, according to Equation 3 :

$$
\mathrm{d}=\sum_{\mathrm{i}=1}^{\mathrm{n}}\left[\mathrm{Db}_{\mathrm{i}} \times\left(\frac{\mathrm{VC}_{\mathrm{i}}}{\sum_{\mathrm{i}=1}^{\mathrm{n}} \mathrm{VC_{i }}}\right]\right)
$$

Where: $\mathbf{n}=$ number of selected species; Dbi $=$ basic density of the ith species selected, in Ton. $\mathrm{m}^{-3}$; and $\mathbf{V C i}=$ average value of coverage of the $\mathrm{i}$-th species with secondary xylem.

The biomass of wood present in the stem of each tree was estimated by multiplying the average wood basic density by volumes of the stems (equation 2), according to Equation 4.

$$
B_{\text {wood }}=d \times x^{-} \times V t
$$

Where:

B = biomass of the stem, in Ton; $\mathbf{d}=$ average basic density of the wood, in Ton. $\mathrm{m}^{-3}$; and $\mathbf{V t}=$ total volume estimated de Stem, in $\mathrm{m}^{3}$.

The carbon stored in the bole biomass was estimated by means of the multiplication of the estimates of biomass obtained by factor 0.5 , considering that the dry biomass contains approximately $50 \%$ of carbon (RIBEIRO et al., 2009; SILVA et al., 2019). Then, the stock of carbon was extrapolated to tons per hectare.

\section{RESULTS AND DISCUSSION}

The forest inventory was planned and executed in order to meet an error limit of $5 \%$ to $95 \%$ probability. Were measured 1224 trees (1257 shafts), distributed in 39 families, 89 taxa were identified at the species level. No dead individuals were found for the 16 sample plots. For the calculation of the sample sufficiency in simple random sampling having as a variable of interest the biomass $\left(\mathrm{m}^{3}\right)$ for lignified individuals, met a $n=16$ sample units (S.U) for the total area of $440.000 \mathrm{~m}^{2}$. Other parametric static parameters of interest for sample sufficiency were: $\mathrm{N}=880$; $\mathrm{S} 2=12.33934717 ; \mathrm{S}=3,512741$; $\mathrm{Std}$. Error= 0,$8781852 ; \mathrm{CV}=32,43165 \% ; \mathrm{Cl}=(9,217306597 \leq \mu \leq 12,44511928)$, so the allocation of 16 plots of $500 \mathrm{~m}^{2}$ during the pilot inventory, was a representative sample for this work, concluding, therefore, that the sampling was sufficient.

Table 1: List of species found on the Nova Canaã farm (Porciúncula / RJ) according to dendrometric variables. Legend: $\Sigma$ $\mathrm{G}\left(\mathrm{m}^{2}\right)$ = sum of the basal area; $\mathrm{DBH} \mathrm{x}$-bar = mean diameter at chest height; $\mathrm{H} \mathrm{x}$-bar = average height value.

\begin{tabular}{c|c|c|c|c|c|c|}
\hline Family & Taxa & Specimens & Stems & $\boldsymbol{\Sigma}$ G $\left(\mathbf{m}^{2}\right)$ & DBH x-bar & H x-bar \\
\hline Lamiaceae & Aegiphila integrifolia & 3 & 3 & 0.036817 & 11.52 & 7.3 \\
Fabaceae & Albizia polycephala & 5 & 5 & 0.10438 & 15.23 & 10.1 \\
Euphorbiaceae & Alchornea glandulosa & 2 & 2 & 0.015794 & 9.18 & 5.0 \\
Sapindaceae & Allophylus edulis & 5 & 5 & 0.090121 & 13.90 & 9.2 \\
Sapindaceae & Allophylus sp.1 & 1 & 1 & 0.004974 & 7.96 & 5.0 \\
Verbenaceae & Aloysia virgata & 1 & 1 & 0.003993 & 7.13 & 3.0
\end{tabular}




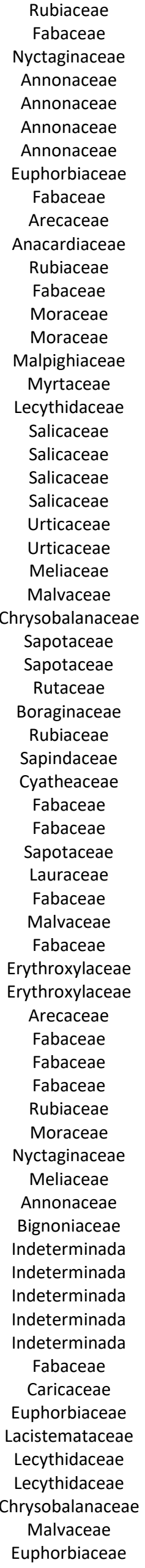

Amaioua guianensis
Anadenanthera colubrina
Andradea floribunda
Annona cacans
Annona dolabripetala
Annona sp.1
Annona sylvatica

Aparisthmium cordatum Apuleia leiocarpa

Astrocaryum aculeatissimum Astronium graveolens Bathysa australis Bauhinia forficata Brosimum guianense Brosimum sp.1 Byrsonima sp.1 Campomanesia guaviroba Cariniana legalis Casearia arborea Casearia commersoniana Casearia sp.1

Casearia sylvestris Cecropia hololeuca

Cecropia pachystachya Cedrela fissilis Ceiba speciosa

Chrysobalanaceae 1

Chrysophyllum aff. gonocarpum Chrysophyllum sp.1 Citrus sp.1

Cordia trichoclada Coussarea sp.1

Cupania oblongifolia Cyathea sp.1 Dalbergia nigra Dalbergia sp.1 Ecclinusa ramiflora Endlicheria sp.1

Enterolobium contortisiliquum Eriotheca sp.1 Erythrina verna

Erythroxylum coelophlebium Erythroxylum pulchrum Euterpe edulis Fabaceae 1 Fabaceae 2 Fabaceae 3 Faramea sp.1 Ficus clusiifolia Guapira opposita Guarea guidonia Guatteria ferruginea Handroanthus chrysotrichus Indeterminada 1 Indeterminada 2 Indeterminada 3 Indeterminada 4 Indeterminada 5 Inga laurina Jacaratia spinosa Joannesia princeps Lacistema pubescens Lecythidaceae sp. Lecythis pisonis Licania sp.1 Luehea divaricata Mabea fistulifera
17

36

1

1

11

2

6

2

34

3

7

12

\begin{tabular}{|c|c|c|c|}
\hline \multirow{2}{*}{$\begin{array}{l}17 \\
37\end{array}$} & 0.090142 & 7.85 & 5.2 \\
\hline & 0.807902 & 12.74 & 7.8 \\
\hline 1 & 0.027513 & 18.72 & 9.0 \\
\hline 1 & 0.058037 & 27.18 & 14.0 \\
\hline 11 & 0.127776 & 11.46 & 9.7 \\
\hline 2 & 0.015751 & 10.01 & 12.0 \\
\hline 11 & 0.056979 & 8.01 & 4.6 \\
\hline 2 & 0.008027 & 6.99 & 5.3 \\
\hline 41 & 0.670099 & 13.56 & 8.8 \\
\hline 3 & 0.02958 & 11.17 & 4.3 \\
\hline 7 & 0.119287 & 13.41 & 8.7 \\
\hline 24 & 0.213667 & 9.96 & 6.0 \\
\hline 1 & 0.042756 & 23.33 & 7.0 \\
\hline 30 & 0.26155 & 9.84 & 6.8 \\
\hline 6 & 0.032493 & 7.97 & 6.7 \\
\hline 4 & 0.363731 & 33.26 & 16.8 \\
\hline 19 & 0.130326 & 8.59 & 5.4 \\
\hline 2 & 0.654893 & 51.65 & 15.3 \\
\hline 3 & 0.008458 & 5.98 & 4.8 \\
\hline 7 & 0.324347 & 18.63 & 11.4 \\
\hline 5 & 0.0447 & 10.15 & 6.4 \\
\hline 21 & 0.209299 & 10.01 & 6.5 \\
\hline 4 & 0.318885 & 30.50 & 16.8 \\
\hline 1 & 0.005175 & 8.12 & 5.0 \\
\hline 3 & 0.181657 & 21.95 & 9.7 \\
\hline 1 & 0.091962 & 34.22 & 20.0 \\
\hline 1 & 0.003057 & 6.24 & 6.0 \\
\hline 4 & 0.018414 & 7.17 & 4.6 \\
\hline 4 & 0.01084 & 5.84 & 5.8 \\
\hline 1 & 0.009582 & 11.05 & 4.5 \\
\hline 2 & 0.022293 & 11.90 & 5.0 \\
\hline 4 & 0.031053 & 9.86 & 8.0 \\
\hline 16 & 0.193104 & 11.18 & 7.1 \\
\hline 1 & 0.009748 & 11.14 & 4.0 \\
\hline 19 & 0.133099 & 8.70 & 5.5 \\
\hline 1 & 0.087734 & 33.42 & 12.0 \\
\hline 3 & 0.10179 & 17.78 & 9.8 \\
\hline 3 & 0.077972 & 15.82 & 6.8 \\
\hline 1 & 0.006418 & 9.04 & 7.5 \\
\hline 1 & 0.052728 & 25.91 & 23.0 \\
\hline 2 & 0.077288 & 20.13 & 11.3 \\
\hline 13 & 0.085478 & 8.79 & 7.0 \\
\hline 47 & 0.751991 & 11.91 & 7.1 \\
\hline 34 & 0.31885 & 10.56 & 7.6 \\
\hline 23 & 0.32707 & 12.54 & 7.2 \\
\hline 1 & 0.261857 & 57.74 & 24.0 \\
\hline 1 & 0.037231 & 21.77 & 15.0 \\
\hline 3 & 0.01745 & 8.37 & 5.7 \\
\hline 1 & 0.560944 & 84.51 & 18.0 \\
\hline 2 & 0.008074 & 6.99 & 4.5 \\
\hline 96 & 3.284336 & 15.78 & 7.8 \\
\hline 34 & 0.565845 & 13.32 & 10.0 \\
\hline 2 & 0.008841 & 7.48 & 5.5 \\
\hline 1 & 0.135522 & 41.54 & 18.0 \\
\hline 1 & 0.013247 & 12.99 & 12.0 \\
\hline 1 & 0.003644 & 6.81 & 5.0 \\
\hline 2 & 0.081733 & 22.65 & 10.0 \\
\hline 1 & 0.017955 & 15.12 & 12.0 \\
\hline 1 & 0.010371 & 11.49 & 7.5 \\
\hline 1 & 0.007647 & 9.87 & 7.0 \\
\hline 1 & 0.014714 & 13.69 & 17.0 \\
\hline 13 & 0.114994 & 9.53 & 6.6 \\
\hline 4 & 0.065493 & 13.23 & 9.5 \\
\hline 1 & 0.035403 & 21.23 & 12.0 \\
\hline 1 & 0.021518 & 16.55 & 13.5 \\
\hline 14 & 0.290585 & 14.18 & 6.8 \\
\hline 29 & 1.516042 & 10.50 & 8.6 \\
\hline
\end{tabular}




\begin{tabular}{|c|c|c|c|c|c|c|}
\hline Fabaceae & Machaerium nyctitans & 2 & 2 & 0.022873 & 11.84 & 7.0 \\
\hline Fabaceae & Machaerium sp.1 & 1 & 1 & 0.046693 & 24.38 & 14.0 \\
\hline Fabaceae & Machaerium sp.2 & 1 & 1 & 0.009472 & 10.98 & 8.0 \\
\hline Fabaceae & Machaerium sp.3 & 1 & 1 & 0.227281 & 53.79 & 23.0 \\
\hline Moraceae & Maclura tinctoria & 1 & 1 & 0.007946 & 10.06 & 7.0 \\
\hline Euphorbiaceae & Maprounea guianensis & 1 & 1 & 0.016114 & 14.32 & 8.0 \\
\hline Sapindaceae & Matayba guianensis & 3 & 3 & 0.018295 & 8.23 & 5.0 \\
\hline Melastomataceae & Miconia dodecandra & 5 & 5 & 0.144859 & 17.91 & 12.0 \\
\hline Melastomataceae & Miconia prasina & 8 & 10 & 0.060135 & 8.30 & 5.8 \\
\hline Melastomataceae & Miconia sp.1 & 1 & 1 & 0.007896 & 10.03 & 9.0 \\
\hline Myrtaceae & Myrcia splendens & 24 & 25 & 0.245366 & 10.49 & 8.1 \\
\hline Primulaceae & Myrsine guianensis & 6 & 6 & 0.094588 & 14.01 & 8.9 \\
\hline Primulaceae & Myrsine sp.1 & 2 & 2 & 0.077319 & 21.77 & 13.5 \\
\hline Lauraceae & Nectandra membranacea & 4 & 4 & 0.173976 & 19.63 & 12.5 \\
\hline Lauraceae & Nectandra oppositifolia & 1 & 1 & 0.008666 & 10.50 & 10.0 \\
\hline Lauraceae & Nectandra sp.1 & 1 & 1 & 0.002578 & 5.73 & 3.0 \\
\hline Lauraceae & Ocotea sp.1 & 1 & 1 & 0.003852 & 7.00 & 5.0 \\
\hline Lauraceae & Ocotea sp.2 & 1 & 1 & 0.056552 & 26.83 & 20.0 \\
\hline Lauraceae & Ocotea sp.3 & 1 & 1 & 0.001962 & 5.00 & 4.5 \\
\hline Ochnaceae & Ouratea cuspidata & 2 & 2 & 0.007394 & 6.78 & 6.0 \\
\hline Piperaceae & Piper amalago & 1 & 1 & 0.0023 & 5.41 & 4.0 \\
\hline Piperaceae & Piper arboreum & 4 & 4 & 0.014879 & 6.73 & 4.3 \\
\hline Fabaceae & Piptadenia gonoacantha & 10 & 10 & 0.593228 & 24.84 & 13.2 \\
\hline Asteraceae & Piptocarpha macropoda & 1 & 1 & 0.033518 & 20.66 & 13.0 \\
\hline Fabaceae & Plathymenia reticulata & 4 & 4 & 0.685817 & 42.76 & 16.5 \\
\hline Fabaceae & Platycyamus regnellii & 9 & 15 & 0.881794 & 25.00 & 13.2 \\
\hline Fabaceae & Platypodium elegans & 2 & 2 & 0.041383 & 14.04 & 9.0 \\
\hline Urticaceae & Pourouma guianensis & 2 & 4 & 0.053255 & 12.22 & 8.8 \\
\hline Sapotaceae & Pouteria aff.guianensis & 1 & 2 & 0.528627 & 44.01 & 20.0 \\
\hline Sapotaceae & Pouteria sp.1 & 1 & 1 & 0.007162 & 9.55 & 5.0 \\
\hline Fabaceae & Pseudopiptadenia contorta & 83 & 85 & 2.33976 & 14.61 & 9.3 \\
\hline Rubiaceae & Psychotria vellosiana & 5 & 5 & 0.013012 & 5.72 & 4.4 \\
\hline Araliaceae & Schefflera morototoni & 1 & 1 & 0.012166 & 12.45 & 12.0 \\
\hline Phytolaccaceae & Seguieria americana & 1 & 2 & 0.005326 & 5.81 & 5.0 \\
\hline Euphorbiaceae & Senefeldera verticillata & 3 & 4 & 0.046944 & 10.96 & 7.1 \\
\hline Fabaceae & Senna macranthera & 1 & 1 & 0.028172 & 18.94 & 13.0 \\
\hline Siparunaceae & Siparuna guianensis & 70 & 74 & 0.242587 & 6.38 & 4.5 \\
\hline Solanaceae & Solanum sp.1 & 1 & 1 & 0.023291 & 17.22 & 10.0 \\
\hline Malvaceae & Spirotheca rivieri & 1 & 1 & 0.003279 & 6.46 & 4.0 \\
\hline Fabaceae & Sweetia fruticosa & 2 & 3 & 0.101536 & 18.47 & 9.8 \\
\hline Arecaceae & Syagrus romanzoffiana & 5 & 5 & 0.081674 & 13.87 & 5.2 \\
\hline Apocynaceae & Tabernaemontana laeta & 1 & 2 & 0.036578 & 14.64 & 6.0 \\
\hline Fabaceae & Tachigali paratyensis & 2 & 2 & 0.17017 & 26.74 & 13.0 \\
\hline Meliaceae & Trichilia elegans & 88 & 95 & 0.719674 & 9.29 & 6.0 \\
\hline Meliaceae & Trichilia hirta & 3 & 3 & 0.050182 & 13.79 & 7.5 \\
\hline Meliaceae & Trichilia pallida & 51 & 51 & 0.295874 & 8.25 & 5.6 \\
\hline Meliaceae & Trichilia sp.1 & 1 & 1 & 0.029903 & 19.51 & 13.0 \\
\hline Myristicaceae & Virola gardneri & 4 & 4 & 0.12367 & 15.34 & 10.4 \\
\hline Annonaceae & Xylopia brasiliensis & 17 & 17 & 0.328091 & 14.71 & 12.4 \\
\hline Annonaceae & Xylopia sericea & 10 & 10 & 0.420654 & 17.62 & 11.1 \\
\hline Rutaceae & Zanthoxylum rhoifolium & 1 & 1 & 0.006284 & 8.94 & 7.5 \\
\hline Bignoniaceae & Zeyheria tuberculosa & 3 & 3 & 0.013966 & 7.44 & 3.8 \\
\hline
\end{tabular}

Among the trees and palm trees found in the arboreal stratum, 125 species were registered, distributed among 41 families (Table 1). The families with the highest species richness were: Fabaceae with 24 species, Lauraceae and Annonaceae with 7 species and Meliaceae and Euphorbiaceae with 6 species. According to Silva et al. (2018), for floristic inventories carried out in the Atlantic Forest biome, Fabaceae and Lauraceae are among the most prominent botanical families. For they are families that have coevolution with many species of fauna, having a high potential for dispersion. While Bignoniaceae, which presented two (2) species, has greater increments of absolute richness for open areas of pastures and scrub, due to the effect of facilitating dispersion of seeds by wind. 
Of the 125 species surveyed, 6 have threat status according to the list of ordinance MMA no 443/2014 and National Center for Conservation of Flora (CNC), they are: Apuleia leiocarpa (Vogel) J.F. Macbr. (CNC-VU; MMA-VU), Dalbergia nigra (Vell.) Allemão ex Benth. (CNC-VU; MMA-VU), Zeyheria tuberculosa (Vell.) Bureau ex Verl. (CNC-VU; MMA-VU), Euterpe edulis Mart. (CNC-VU; MMA-VU), Cedrela fissilis Vell. (CNC-VU; MMAVU) and Cariniana legalis (Mart.) Kuntze (CNC-VU; MMA-VU).

The diameters of the trees measured $(\mathrm{DBH})$ in the inventory were distributed in five classes with an amplitude of $18 \mathrm{~cm}$ (Figure 2), whose distribution of frequencies is shown in Figure 2. The configuration of the graph in the form of an inverted ' $\mathrm{J}$ ', characteristic of natural forests where there are all gradations of age and size, and there are also several stages of regeneration. In native forests, there is a great diversity of species, in consonance with the disposition of distinct luminosity and other influential factors for this high differentiation. Silva et al. (2017) consider it as expected, for this type of forest formation, where the sampled area is largely composed of initial secondary species. Such species have abundant regeneration characteristics, concentrating large numbers of individuals in the first diameter classes.

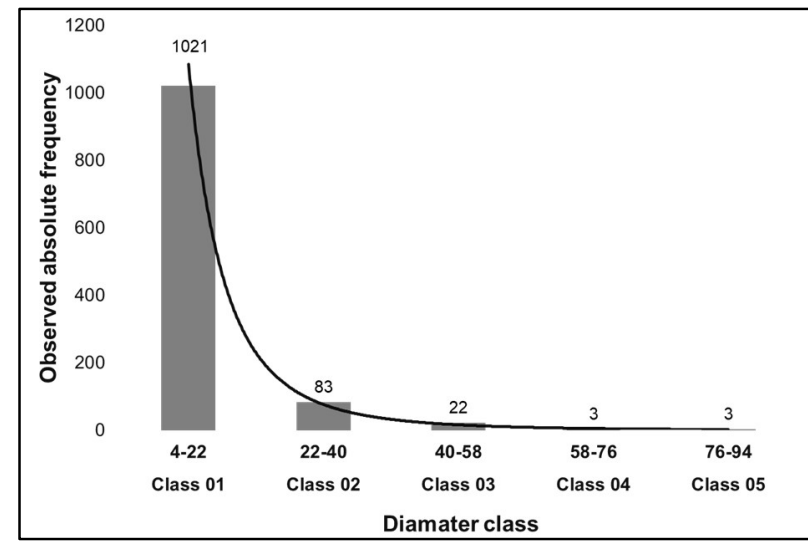

Figure 2: Distribution of frequency per class of DBH of trees measured.

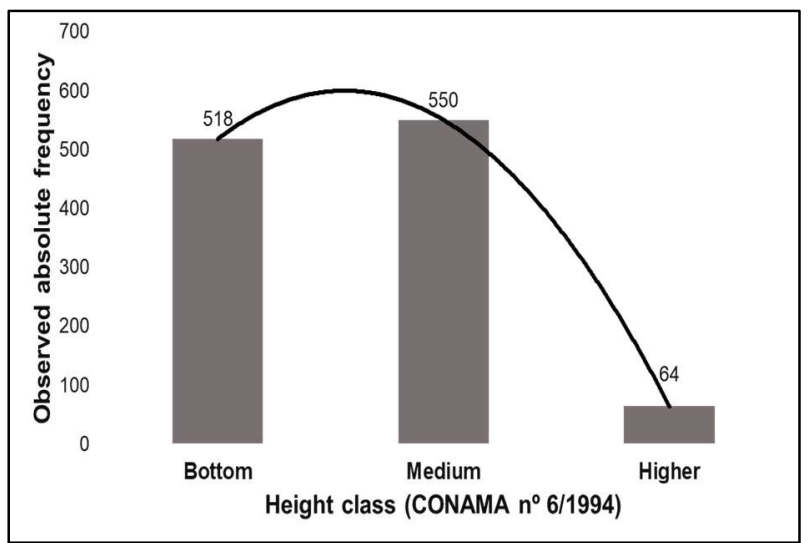

Figure 3: The vertical structure of the forest ecosystem.

According to Martins (1991), the height estimates of shrub and tree individuals can provide important information both for the interpretation of vertical forest structure and to help understand the population dynamics that compose it. The heights of the trees measured in the inventory were divided into three classes (Figure 3), bottom $<6.2 \mathrm{~m}$, medium $6.2 \mathrm{~m}<14.2 \mathrm{~m}$ and higher $>14.2 \mathrm{~m}$ according to CONAMA Resolution $\mathrm{n}^{\circ}$ 06/1994. Of the 1132 trees measured, 518 individuals are in the lower stratum, 550 in the middle stratum and 64 in the upper stratum. The species that presented individuals with the highest average height increments were: Ceiba speciosa, Ocotea sp.2, Pouteria aff.guianensis, Ficus clusiifolia and Joannesia princeps, all with specimens whose heights exceed or equal $17 \mathrm{~m}$. Indicating a regeneration environment and recruiting new individuals in each stratum of the forest ecosystem.

For the biomass analysis $\left(\mathrm{m}^{3}\right)$, in the $8.000 \mathrm{~m}^{2}$ of study area, $172.3614 \mathrm{~m}^{3}$ of biomass were quantified, distributed to the 16 sample plots (Figure 4), as well as for each hectare of woody area of the Nova Canaã farm it is expected the quantification of $215.4517 \mathrm{~m}^{3}$. The families that showed the highest biomass expression in m3 (Table 2) are: Fabaceae $\left(67,592 \mathrm{~m}^{3}\right)$, Meliaceae $\left(26.615 \mathrm{~m}^{3}\right)$ and Annonaceae $\left(12.378 \mathrm{~m}^{3}\right)$. 


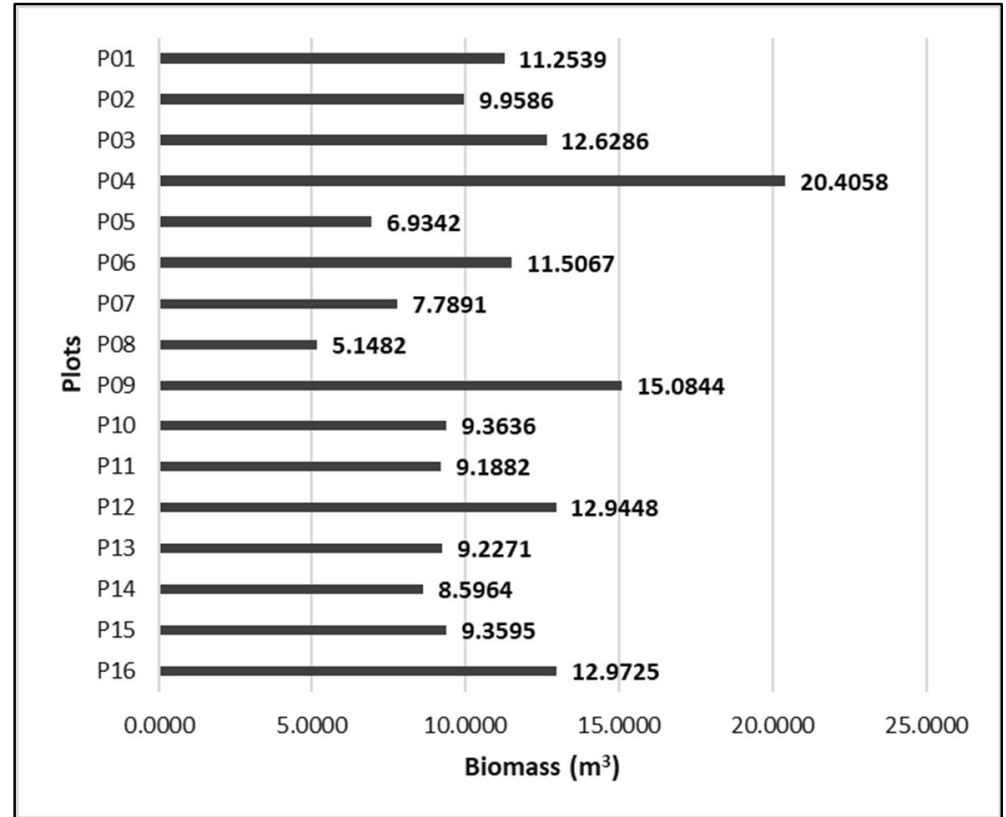

Figure 4: Biomass $\left(\mathrm{m}^{3}\right)$ per plot.

Table 2: Total biomass $\left(\mathrm{m}^{3}\right)$, by sampled botanical family.

\begin{tabular}{|c|c|}
\hline Botanical Families & $\Sigma$ Biomass $\left(\mathrm{m}^{3}\right)$ \\
\hline Fabaceae & 67.592 \\
\hline Meliaceae & 26.615 \\
\hline Annonaceae & 12.378 \\
\hline Euphorbiaceae & 9.417 \\
\hline Lecythidaceae & 7.148 \\
\hline Moraceae & 5.867 \\
\hline Salicaceae & 4.830 \\
\hline Sapotacaeae & 4.617 \\
\hline Erythroxylaceae & 4.592 \\
\hline Urticaceae & 3.526 \\
\hline Malpighiaceae & 3.519 \\
\hline Malvaceae & 3.338 \\
\hline Lauraceae & 3.104 \\
\hline Indeterminada & 2.000 \\
\hline Myrtaceae & 1.951 \\
\hline Rubiaceae & 1.758 \\
\hline Sapindaceae & 1.721 \\
\hline Myristicaceae & 1.334 \\
\hline Melastomataceae & 1.251 \\
\hline Primulaceae & 1.189 \\
\hline Sapotaceae & 0.829 \\
\hline Siparunaceae & 0.781 \\
\hline Anacardiaceae & 0.778 \\
\hline Lacistemataceae & 0.655 \\
\hline Asteraceae & 0.262 \\
\hline Chrysobalanaceae & 0.201 \\
\hline Lamiaceae & 0.187 \\
\hline Nyctaginaceae & 0.170 \\
\hline Apocynaceae & 0.148 \\
\hline Solanaceae & 0.141 \\
\hline Araliaceae & 0.100 \\
\hline Bignoniaceae & 0.069 \\
\hline Boraginaceae & 0.067 \\
\hline Rutaceae & 0.059 \\
\hline Piperaceae & 0.052 \\
\hline Caricaceae & 0.036 \\
\hline Ochnaceae & 0.034 \\
\hline Phytolaccaceae & 0.020 \\
\hline Verbenaceae & 0.008 \\
\hline
\end{tabular}


Among the 121 species endowed with secondary xylem, the most representative in biomass $\left(\mathrm{m}^{3}\right)$ was Pseudopiptadenia contorta, the second was Guarea guidonia, the two alone represent about 25.21\% of biomass $\left(\mathrm{m}^{3}\right)$ in the analyzed forest community. These species also had the highest coverage (CV), importance value (IV) and stored carbon per hectare (Table 3). As for the ecological diversity of the study area, the Shannon-Weaver Index of 3.748 nats. Ind ${ }^{-1}$ was found, a value considered high for the Atlantic Forest according to CONAMA Resolution $n^{\circ} 06 / 1994$ and the Pielou Equitability was 0.7762 . Indicating that there is a dominance in forest biocenosis, regarding the distribution of species to the sample allocation space of the 16 plots (S.U).

Table 3: List of species found on the Nova Canaã farm (Porciúncula/RJ) according to the importance value (IV) and the coverage value (CV). Legend: $\mathrm{Vl}=$ importance value; $\mathrm{CV}=$ coverage value; $\mathrm{B}_{\text {wood }}=$ wood biomass; $\mathrm{SC}=$ stored carbon.

\begin{tabular}{|c|c|c|c|c|c|c|c|c|}
\hline Nome Científico & $\Sigma$ Biomass $\left(m^{3}\right)$ & $\begin{array}{l}\text { Biomass } \\
\left(\mathrm{m}^{2} \mathrm{ha}^{-1}\right)\end{array}$ & $\begin{array}{c}\rho \text { wood } \\
\text { (ton } / \mathrm{m}^{3} \text { ) }\end{array}$ & IV & CV & $\begin{array}{c}\text { B } \text { wood } \\
\text { (ton } / \mathrm{m}^{3}\end{array}$ & $S C(t)$ & $\begin{array}{c}\mathrm{SC} \\
\left(\mathrm{tC} \cdot \mathrm{ha}^{-1}\right)\end{array}$ \\
\hline Guarea guidonia & 20.554 & 25.6925 & 0.76 & 22.84 & 21.18 & 137.3251 & 68.66257 & 85.828218 \\
\hline Pseudopiptadenia contorta & 22.909 & 28.63625 & 0.62 & 19.86 & 17.2 & 101.3834 & 50.69168 & 63.364601 \\
\hline Mabea fistulifera & 8.836 & 11.045 & 0.5 & 18.13 & 16.46 & 41.4629 & 20.73145 & 25.914314 \\
\hline Trichilia elegans & 3.083 & 3.85375 & 0.78 & 12.8 & 10.81 & 11.43633 & 5.718164 & 7.1477053 \\
\hline Anadenanthera colubrina & 6.939 & 8.67375 & 0.93 & 8.248 & 6.587 & 7.651238 & 3.825619 & 4.7820239 \\
\hline Erythroxylum pulchrum & 4.157 & 5.19625 & 0.85 & 9.893 & 7.235 & 5.879604 & 2.939802 & 3.6747524 \\
\hline Apuleia leiocarpa & 4.503 & 5.62875 & 0.83 & 1.054 & 0.39 & 3.703753 & 1.851876 & 2.3148456 \\
\hline Guatteria ferruginea & 4.181 & 5.22625 & 0.59 & 6.874 & 5.213 & 2.057721 & 1.02886 & 1.2860755 \\
\hline Trichilia pallida & 1.272 & 1.59 & 0.74 & 7.746 & 5.753 & 1.380364 & 0.690182 & 0.8627275 \\
\hline Platycyamus regnellii & 7.959 & 9.94875 & 0.81 & 5.51 & 4.514 & 1.30942 & 0.65471 & 0.8183875 \\
\hline Siparuna guianensis & 0.781 & 0.97625 & 0.43 & 11.19 & 7.207 & 0.846975 & 0.423488 & 0.5293594 \\
\hline Piptadenia gonoacantha & 5.171 & 6.46375 & 0.75 & 4.714 & 3.385 & 0.656432 & 0.328216 & 0.4102702 \\
\hline Xylopia brasiliensis & 3.016 & 3.77 & 0.7 & 4.214 & 2.885 & 0.517845 & 0.258922 & 0.3236528 \\
\hline Brosimum guianense & 1.429 & 1.78625 & 0.88 & 5.881 & 3.223 & 0.486265 & 0.243132 & 0.3039154 \\
\hline Myrcia splendens & 1.468 & 1.835 & 0.79 & 5.148 & 3.155 & 0.43903 & 0.219515 & 0.2743938 \\
\hline Xylopia sericea & 3.469 & 4.33625 & 0.7 & 3.986 & 2.657 & 0.322686 & 0.161343 & 0.2016787 \\
\hline Fabaceae 1 & 1.712 & 2.14 & 0.7 & 4.122 & 2.793 & 0.26776 & 0.13388 & 0.1673498 \\
\hline Plathymenia reticulata & 6.038 & 7.5475 & 0.55 & 4.242 & 3.246 & 0.215548 & 0.107774 & 0.1347172 \\
\hline Casearia commersoniana & 3.556 & 4.445 & 0.84 & 2.562 & 1.898 & 0.170064 & 0.085032 & 0.1062899 \\
\hline Luehea divaricata & 1.553 & 1.94125 & 0.64 & 4.699 & 2.374 & 0.153409 & 0.076704 & 0.0958804 \\
\hline Casearia sylvestris & 1.032 & 1.29 & 0.7 & 3.713 & 2.384 & 0.146434 & 0.073217 & 0.091521 \\
\hline Byrsonima sp.1 & 3.519 & 4.39875 & 0.78 & 2.552 & 1.887 & 0.103609 & 0.051805 & 0.0647556 \\
\hline Dalbergia nigra & 0.544 & 0.68 & 0.87 & 4.898 & 2.24 & 0.100771 & 0.050385 & 0.0629817 \\
\hline Cariniana legalis & 6.399 & 7.99875 & 0.53 & 3.603 & 2.938 & 0.099661 & 0.04983 & 0.062288 \\
\hline Bathysa australis & 0.966 & 1.2075 & 0.64 & 2.958 & 1.961 & 0.072746 & 0.036373 & 0.0454664 \\
\hline Cupania oblongifolia & 1.028 & 1.285 & 0.67 & 2.451 & 1.786 & 0.067691 & 0.033845 & 0.0423067 \\
\hline Campomanesia guaviroba & 0.483 & 0.60375 & 0.76 & 3.717 & 2.055 & 0.064109 & 0.032054 & 0.0400679 \\
\hline Annona dolabripetala & 0.938 & 1.1725 & 0.61 & 3.504 & 1.511 & 0.047544 & 0.023772 & 0.0297149 \\
\hline Erythroxylum coelophlebium & 0.435 & 0.54375 & 1 & 2.506 & 1.509 & 0.042643 & 0.021321 & 0.0266517 \\
\hline Pouteria aff.guianensis & 4.594 & 5.7425 & 0.71 & 2.65 & 2.318 & 0.037799 & 0.0189 & 0.0236244 \\
\hline Amaioua guianensis & 0.347 & 0.43375 & 0.67 & 3.875 & 1.882 & 0.037155 & 0.018577 & 0.0232218 \\
\hline Lacistema pubescens & 0.655 & 0.81875 & 0.57 & 2.542 & 1.545 & 0.034609 & 0.017304 & 0.0216305 \\
\hline Cecropia hololeuca & 3.138 & 3.9225 & 0.43 & 2.606 & 1.61 & 0.032584 & 0.016292 & 0.0203647 \\
\hline Astronium graveolens & 0.778 & 0.9725 & 0.97 & 2.45 & 1.121 & 0.02961 & 0.014805 & 0.0185063 \\
\hline Nectandra membranacea & 1.992 & 2.49 & 0.65 & 1.751 & 1.087 & 0.028145 & 0.014072 & 0.0175905 \\
\hline Miconia dodecandra & 0.957 & 1.19625 & 0.73 & 2.049 & 1.053 & 0.018375 & 0.009188 & 0.0114845 \\
\hline Ficus clusiifolia & 4.242 & 5.3025 & 0.34 & 2.786 & 2.454 & 0.017696 & 0.008848 & 0.0110601 \\
\hline Virola gardneri & 1.334 & 1.6675 & 0.56 & 1.539 & 0.875 & 0.013072 & 0.006536 & 0.00817 \\
\hline Fabaceae 2 & 3.098 & 3.8725 & 0.7 & 1.525 & 1.193 & 0.012934 & 0.006467 & 0.0080835 \\
\hline Albizia polycephala & 0.741 & 0.92625 & 0.7 & 2.543 & 0.882 & 0.011433 & 0.005717 & 0.0071459 \\
\hline Machaerium sp.3 & 2.612 & 3.265 & 0.8 & 1.379 & 1.047 & 0.010939 & 0.005469 & 0.0068368 \\
\hline Cedrela fissilis & 1.196 & 1.495 & 0.55 & 1.363 & 1.031 & 0.010177 & 0.005089 & 0.0063609 \\
\hline Myrsine guianensis & 0.568 & 0.71 & 0.61 & 1.593 & 0.929 & 0.00965 & 0.004825 & 0.0060312 \\
\hline Tachigali paratyensis & 1.906 & 2.3825 & 0.52 & 1.227 & 0.894 & 0.008862 & 0.004431 & 0.0055385 \\
\hline Allophylus edulis & 0.621 & 0.77625 & 0.64 & 1.818 & 0.822 & 0.00816 & 0.00408 & 0.0051001 \\
\hline Ecclinusa ramiflora & 0.711 & 0.88875 & 0.95 & 1.027 & 0.694 & 0.007031 & 0.003516 & 0.0043946 \\
\hline
\end{tabular}


Miconia prasina

Sweetia fruticosa

Annona sylvatica

Indeterminada 1

Lecythidaceae sp.

Brosimum sp.1

Myrsine sp.1

Casearia sp.1

Trichilia hirta

Senefeldera verticillata

Dalbergia sp.1

Erythrina verna

Platypodium elegans Ocotea sp.2

Ceiba speciosa

Aegiphila integrifolia

Indeterminada 4

Pourouma guianensis

Eriotheca sp.1

Annona cacans

Endlicheria sp.1

Psychotria vellosiana

Machaerium sp.1

Coussarea sp.1

Machaerium nyctitans

Zeyheria tuberculosa

Fabaceae 3

Lecythis pisonis

Trichilia sp.1

Annona sp.1

Faramea sp.1

Bauhinia forficata

Licania sp.1

Matayba guianensis

Chrysophyllum sp.1

Piper arboreum

Piptocarpha macropoda

Senna macranthera

Andradea floribunda

Chrysophyllum aff. gonocarpum Casearia arborea

Tabernaemontana laeta Cordia trichoclada Solanum sp.1

Indeterminada 5

Handroanthus chrysotrichus

Joannesia princeps

Alchornea glandulosa

Indeterminada 2

Guapira opposita

Ouratea cuspidata

Maprounea guianensis

Schefflera morototoni

Aparisthmium cordatum

Machaerium sp.2

Inga laurina

Miconia sp.1

Nectandra oppositifolia

Maclura tinctoria

Pouteria sp.1

Enterolobium contortisiliquum

Zanthoxylum rhoifolium Citrus sp.1

Seguieria americana

Allophylus sp. 1

Chrysobalanaceae 1

Indeterminada 3

\begin{tabular}{|c|c|c|}
\hline 245 & 0.30625 & 0.73 \\
\hline 0.792 & 0.99 & 0.99 \\
\hline 0.179 & 0.22375 & 0.61 \\
\hline 1.262 & 1.5775 & 0.6 \\
\hline 0.5 & 0.625 & 0.6 \\
\hline 0.159 & 0.19875 & 0.88 \\
\hline 0.621 & 0.77625 & 0.61 \\
\hline 0.212 & 0.265 & 0.7 \\
\hline 0.272 & 0.34 & 0.78 \\
\hline 0.233 & 0.29125 & 0.79 \\
\hline 0.542 & 0.6775 & 0.87 \\
\hline 0.612 & 0.765 & 0.32 \\
\hline 0.33 & 0.4125 & 0.82 \\
\hline 0.677 & 0.84625 & 0.76 \\
\hline 1.025 & 1.28125 & 0.34 \\
\hline 0.187 & 0.23375 & 0.68 \\
\hline 0.478 & 0.5975 & 0.68 \\
\hline 0.37 & 0.4625 & 0.42 \\
\hline 0.751 & 0.93875 & 0.43 \\
\hline 0.456 & 0.57 & 0.61 \\
\hline 0.35 & 0.4375 & 0.58 \\
\hline 0.041 & 0.05125 & 0.7 \\
\hline 0.379 & 0.47375 & 0.66 \\
\hline 0.175 & 0.21875 & 0.65 \\
\hline 0.106 & 0.1325 & 1.12 \\
\hline 0.035 & 0.04375 & 1.8 \\
\hline 0.338 & 0.4225 & 0.7 \\
\hline 0.25 & 0.3125 & 0.88 \\
\hline 0.237 & 0.29625 & 0.84 \\
\hline 0.138 & 0.1725 & 0.61 \\
\hline 0.073 & 0.09125 & 0.53 \\
\hline 0.156 & 0.195 & 0.9 \\
\hline 0.187 & 0.23375 & 0.99 \\
\hline 0.055 & 0.06875 & 0.57 \\
\hline 0.049 & 0.06125 & 0.7 \\
\hline 0.045 & 0.05625 & 0.4 \\
\hline 0.262 & 0.3275 & 0.45 \\
\hline 0.226 & 0.2825 & 0.55 \\
\hline 0.144 & 0.18 & 0.85 \\
\hline 0.069 & 0.08625 & 0.7 \\
\hline 0.03 & 0.0375 & 0.84 \\
\hline 0.148 & 0.185 & 0.6 \\
\hline 0.067 & 0.08375 & 0.5 \\
\hline 0.141 & 0.17625 & 0.64 \\
\hline 0.14 & 0.175 & 0.7 \\
\hline 0.034 & 0.0425 & 1.01 \\
\hline 0.177 & 0.22125 & 0.52 \\
\hline 0.06 & 0.075 & 0.4 \\
\hline 0.108 & 0.135 & 0.65 \\
\hline 0.026 & 0.0325 & 0.83 \\
\hline 0.034 & 0.0425 & 0.64 \\
\hline 0.079 & 0.09875 & 0.72 \\
\hline 0.1 & 0.125 & 0.62 \\
\hline 0.031 & 0.03875 & 0.52 \\
\hline 0.05 & 0.0625 & 1.04 \\
\hline 0.051 & 0.06375 & 0.71 \\
\hline 0.05 & 0.0625 & 0.73 \\
\hline 0.061 & 0.07625 & 0.54 \\
\hline 0.037 & 0.04625 & 0.88 \\
\hline 0.023 & 0.02875 & 0.94 \\
\hline 0.034 & 0.0425 & 0.54 \\
\hline 0.033 & 0.04125 & 0.5 \\
\hline 0.026 & 0.0325 & 0.54 \\
\hline 0.02 & 0.025 & 0.59 \\
\hline 0.017 & 0.02125 & 0.64 \\
\hline 0.014 & 0.0175 & 0.7 \\
\hline 0.013 & 0.01625 & 0.67 \\
\hline
\end{tabular}

$\begin{array}{lllll}2.621 & 0.96 & 0.006878 & 0.003439 & 0.0042987\end{array}$

$\begin{array}{llllll}1.269 & 0.605 & 0.004743 & 0.002372 & 0.0029645\end{array}$

$\begin{array}{llllll}1.767 & 0.77 & 0.002522 & 0.001261 & 0.0015761\end{array}$

$\begin{array}{llllll}0.992 & 0.66 & 0.002497 & 0.001249 & 0.0015609\end{array}$

$\begin{array}{llllll}0.873 & 0.541 & 0.002433 & 0.001217 & 0.0015208\end{array}$

$\begin{array}{llllll}0.911 & 0.579 & 0.002023 & 0.001011 & 0.0012642\end{array}$

$\begin{array}{llllll}1.167 & 0.503 & 0.001904 & 0.000952 & 0.0011902\end{array}$

$\begin{array}{llllll}0.874 & 0.542 & 0.001608 & 0.000804 & 0.0010051\end{array}$

$\begin{array}{llllll}1.141 & 0.477 & 0.001519 & 0.00076 & 0.0009496\end{array}$

$\begin{array}{llllll}0.795 & 0.463 & 0.001277 & 0.000639 & 0.0007983\end{array}$

$\begin{array}{llllll}0.791 & 0.458 & 0.00108 & 0.00054 & 0.0006752\end{array}$

$\begin{array}{lllll}1.167 & 0.503 & 0.000985 & 0.000492 & 0.0006153\end{array}$

$\begin{array}{llllll}1.016 & 0.351 & 0.000951 & 0.000475 & 0.0005941\end{array}$

$\begin{array}{llllll}0.659 & 0.327 & 0.00084 & 0.00042 & 0.0005252\end{array}$

$\begin{array}{llllll}0.808 & 0.476 & 0.00083 & 0.000415 & 0.0005185\end{array}$

$\begin{array}{llllll}1.417 & 0.42 & 0.000804 & 0.000402 & 0.0005023\end{array}$

$\begin{array}{llllll}0.765 & 0.433 & 0.000704 & 0.000352 & 0.0004398\end{array}$

$\begin{array}{llllll}0.733 & 0.401 & 0.000624 & 0.000312 & 0.0003901\end{array}$

$\begin{array}{llllll}0.643 & 0.311 & 0.000501 & 0.000251 & 0.0003133\end{array}$

$\begin{array}{llllll}0.665 & 0.333 & 0.000463 & 0.000232 & 0.0002895\end{array}$

$\begin{array}{llllll}0.749 & 0.417 & 0.000423 & 0.000212 & 0.0002646\end{array}$

$\begin{array}{llllll}0.829 & 0.497 & 0.00036 & 0.00018 & 0.0002253\end{array}$

$\begin{array}{llllll}0.617 & 0.285 & 0.000356 & 0.000178 & 0.0002228\end{array}$

$\begin{array}{llllll}0.972 & 0.308 & 0.00035 & 0.000175 & 0.0002185\end{array}$

$\begin{array}{llllll}0.938 & 0.273 & 0.000325 & 0.000162 & 0.0002029\end{array}$

$\begin{array}{llllll}0.988 & 0.324 & 0.000308 & 0.000154 & 0.0001928\end{array}$

$\begin{array}{llllll}0.578 & 0.245 & 0.000291 & 0.000145 & 0.0001816\end{array}$

$\begin{array}{llllll}0.57 & 0.238 & 0.000261 & 0.000131 & 0.0001632\end{array}$

$\begin{array}{llllll}0.547 & 0.214 & 0.000214 & 0.000107 & 0.0001336\end{array}$

$\begin{array}{llllll}0.575 & 0.243 & 0.000205 & 0.000102 & 0.0001279\end{array}$

$\begin{array}{llllll}0.671 & 0.339 & 0.000195 & 9.77 \mathrm{E}-05 & 0.0001222\end{array}$

$\begin{array}{llllll}0.601 & 0.269 & 0.000189 & 9.45 \mathrm{E}-05 & 0.0001181\end{array}$

$\begin{array}{llllll}0.511 & 0.179 & 0.000166 & 8.30 \mathrm{E}-05 & 0.0001038\end{array}$

$\begin{array}{llllll}1.339 & 0.342 & 0.000162 & 8.10 \mathrm{E}-05 & 0.0001012\end{array}$

$\begin{array}{llllll}0.643 & 0.311 & 0.000159 & 7.97 \mathrm{E}-05 & 0.0000996\end{array}$

$\begin{array}{llllll}1.413 & 0.416 & 0.00015 & 7.52 \mathrm{E}-05 & 9.404 \mathrm{E}-05\end{array}$

$\begin{array}{lllll}0.562 & 0.23 & 0.000135 & 6.76 \mathrm{E}-05 & 8.453 \mathrm{E}-05\end{array}$

$\begin{array}{lllll}0.539 & 0.207 & 0.000129 & 6.43 \mathrm{E}-05 & 8.033 \mathrm{E}-05\end{array}$

$\begin{array}{lllll}0.537 & 0.204 & 0.000125 & 6.25 \mathrm{E}-05 & 7.81 \mathrm{E}-05\end{array}$

$\begin{array}{lllll}0.919 & 0.254 & 0.000123 & 6.15 \mathrm{E}-05 & 7.693 \mathrm{E}-05\end{array}$

$\begin{array}{lllll}0.965 & 0.301 & 0.000114 & 5.68 \mathrm{E}-05 & 7.103 \mathrm{E}-05\end{array}$

$\begin{array}{lllll}0.575 & 0.243 & 0.000108 & 5.39 \mathrm{E}-05 & 6.741 \mathrm{E}-05\end{array}$

$0.935 \quad 0.271 \quad 9.13 \mathrm{E}-05 \quad 4.57 \mathrm{E}-05 \quad 5.708 \mathrm{E}-05$

$0.519 \quad 0.187 \quad 8.43 \mathrm{E}-05 \quad 4.21 \mathrm{E}-05 \quad 5.267 \mathrm{E}-05$

$0.496 \quad 0.164 \quad 8.03 \mathrm{E}-05 \quad 4.02 \mathrm{E}-05 \quad 5.02 \mathrm{E}-05$

$0.546 \quad 0.214 \quad 7.33 \mathrm{E}-05 \quad 3.67 \mathrm{E}-05 \quad 4.582 \mathrm{E}-05$

$0.483 \quad 0.15 \quad 6.93 \mathrm{E}-05 \quad 3.47 \mathrm{E}-05 \quad 4.333 \mathrm{E}-05$

$0.908 \quad 0.243 \quad 5.79 \mathrm{E}-05 \quad 2.90 \mathrm{E}-05 \quad 3.621 \mathrm{E}-05$

$0.476 \quad 0.144 \quad 5.06 \mathrm{E}-05 \quad 2.53 \mathrm{E}-05 \quad 3.16 \mathrm{E}-05$

$0.875 \quad 0.211 \quad 4.51 \mathrm{E}-05 \quad 2.26 \mathrm{E}-05 \quad 2.82 \mathrm{E}-05$

$0.54 \quad 0.208 \quad 4.50 \mathrm{E}-05 \quad 2.25 \mathrm{E}-05 \quad 2.812 \mathrm{E}-05$

$0.489 \quad 0.156 \quad 4.47 \mathrm{E}-05 \quad 2.23 \mathrm{E}-05 \quad 2.792 \mathrm{E}-05$

$0.472 \quad 0.14 \quad 4.34 \mathrm{E}-05 \quad 2.17 \mathrm{E}-05 \quad 2.715 \mathrm{E}-05$

$0.875 \quad 0.211 \quad 3.41 \mathrm{E}-05 \quad 1.70 \mathrm{E}-05 \quad 2.129 \mathrm{E}-05$

$\begin{array}{lllll}0.461 & 0.128 & 3.37 \mathrm{E}-05 & 1.68 \mathrm{E}-05 & 2.103 \mathrm{E}-05\end{array}$

$0.464 \quad 0.132 \quad 2.37 \mathrm{E}-05 \quad 1.18 \mathrm{E}-05 \quad 1.481 \mathrm{E}-05$

$0.454 \quad 0.122 \quad 2.20 \mathrm{E}-05 \quad 1.10 \mathrm{E}-05 \quad 1.375 \mathrm{E}-05$

$0.457 \quad 0.125 \quad 2.05 \mathrm{E}-05 \quad 1.02 \mathrm{E}-05 \quad 1.279 \mathrm{E}-05$

$0.454 \quad 0.122 \quad 1.99 \mathrm{E}-05 \quad 9.96 \mathrm{E}-06 \quad 1.245 \mathrm{E}-05$

$\begin{array}{lllll}0.451 & 0.119 & 1.28 \mathrm{E}-05 & 6.39 \mathrm{E}-06 & 7.989 \mathrm{E}-06\end{array}$

$0.448 \quad 0.115 \quad 1.05 \mathrm{E}-05 \quad 5.23 \mathrm{E}-06 \quad 6.535 \mathrm{E}-06$

$\begin{array}{lllll}0.447 & 0.115 & 9.46 \mathrm{E}-06 & 4.73 \mathrm{E}-06 & 5.913 \mathrm{E}-06\end{array}$

$0.461 \quad 0.129 \quad 9.04 \mathrm{E}-06 \quad 4.52 \mathrm{E}-06 \quad 5.65 \mathrm{E}-06$

$0.443 \quad 0.111 \quad 6.44 \mathrm{E}-06 \quad 3.22 \mathrm{E}-06 \quad 4.023 \mathrm{E}-06$

$0.442 \quad 0.109 \quad 5.88 \mathrm{E}-06 \quad 2.94 \mathrm{E}-06 \quad 3.674 \mathrm{E}-06$

$0.433 \quad 0.101 \quad 4.86 \mathrm{E}-06 \quad 2.43 \mathrm{E}-06 \quad 3.04 \mathrm{E}-06$

$\begin{array}{lllll}0.436 & 0.104 & 4.48 \mathrm{E}-06 & 2.24 \mathrm{E}-06 & 2.798 \mathrm{E}-06\end{array}$ 


\begin{tabular}{ccccccccc} 
Ocotea sp.1 & 0.014 & 0.0175 & 0.62 & 0.437 & 0.105 & $4.38 \mathrm{E}-06$ & $2.19 \mathrm{E}-06$ & $2.738 \mathrm{E}-06$ \\
Cecropia pachystachya & 0.017 & 0.02125 & 0.41 & 0.442 & 0.11 & $3.93 \mathrm{E}-06$ & $1.96 \mathrm{E}-06$ & $2.454 \mathrm{E}-06$ \\
Aloysia virgata & 0.008 & 0.01 & 0.6 & 0.437 & 0.105 & $2.42 \mathrm{E}-06$ & $1.21 \mathrm{E}-06$ & $1.512 \mathrm{E}-06$ \\
Spirotheca rivieri & 0.009 & 0.01125 & 0.5 & 0.434 & 0.102 & $2.32 \mathrm{E}-06$ & $1.16 \mathrm{E}-06$ & $1.448 \mathrm{E}-06$ \\
Ocotea sp.3 & 0.007 & 0.00875 & 0.66 & 0.429 & 0.097 & $2.14 \mathrm{E}-06$ & $1.07 \mathrm{E}-06$ & $1.338 \mathrm{E}-06$ \\
Nectandra sp.1 & 0.005 & 0.00625 & 0.77 & 0.431 & 0.099 & $2.02 \mathrm{E}-06$ & $1.01 \mathrm{E}-06$ & $1.26 \mathrm{E}-06$ \\
Piper amalago & 0.007 & 0.00875 & 0.4 & 0.43 & 0.098 & $1.31 \mathrm{E}-06$ & $6.57 \mathrm{E}-07$ & $8.213 \mathrm{E}-07$ \\
Jacaratia spinosa & 0.036 & 0.045 & 0.01 & 0.453 & 0.121 & $2.17 \mathrm{E}-07$ & $1.08 \mathrm{E}-07$ & $1.355 \mathrm{E}-07$ \\
Astrocaryum aculeatissimum & - & - & - & 8.819 & 5.829 & - & - & - \\
Cyathea sp.1 & - & - & - & 0.462 & 0.129 & - & - & - \\
Euterpe edulis & - & - & - & 5.921 & 4.26 & - & - & - \\
Syagrus romanzoffiana & - & - & - & 1.783 & 0.786 & - & - & - \\
\hline
\end{tabular}

For the quantification of wood biomass ( $\left.B_{\text {wood }}\right), 318.7802 \mathrm{t}$ were found for the total area of $8000 \mathrm{~m}^{2}$, which correspond to the 16 plots (S.U), extrapolating this result to hectares, we will have $398.4753 \mathrm{t}^{\text {t ha-1 }}{ }^{-1}$. As for the stored carbon (SC), the value of $199.2377 \mathrm{tC} . \mathrm{ha}^{-1}$ was obtained.

The biomass and carbon estimates found were similar to studies in which biomass estimates were obtained from the shelless stem of Ribeiro et al. (2009), which accounted for 319 tree species, belonging to 177 genera and 60 families. The quantification of biomass (Bwood) of the stem bark resulted in estimates of 166.67.ha- ${ }^{-1}$, for a carbon stock of 83.34 tC. ha ${ }^{-1}$, in a mature forest in Viçosa, MG according to CONAMA Resolution $n^{\circ} 29 / 1994$. Silva et al. (2019), sampled for the initial (ecesis) and medium forest ecosystem of the Billings Reservoir in São Bernardo do Campo (SP) the value of 113,73 t.ha $^{-1}$ which corresponded to 56.87 tC.ha ${ }^{-1}$ stored carbon. Silva et al. (2018), conducted a similar study for the Municipal Natural Park of Curió, whose specie of greatest importance was also Guarea guidonia, the estimated wood biomass was 212.39 t.ha ${ }^{-1}$ and the stored carbon was 106, 19 tC.ha ${ }^{-1}$. In comparison with these studies, the density of species per sampling unit of the forest ecosystem of the Nova Canaã farm was the main differentiating factor, hence the abundance of individuals per hectare was two to three times higher compared to the other studies cited here.

The dendrometric variables for the secondary stage forest ecosystem (Table 1), in turn, are in accordance with that presented in CONAMA Resolution $n^{\circ} 06 / 1994$, for forests in early and medium stages. According to Fukuda et al. (2003), younger forests tend to use more carbon than mature ones. It is also noteworthy that the forest ecosystem of the Nova Canaã farm has large densities of the species Syagrus romanzoffiana, Cyathea sp.1, Astrocaryum aculeatissimum and Euterpe edulis, species that do not produce secondary xylem, as mentioned before. Therefore, it is important to use other methods of measuring biomass and carbon storage in non-lignified vegetables, preferably non-destructive methods. It is important to note that the species Euterpe edulis is threatened and endemic to the Atlantic Forest and the species Cyathea sp.1 is of great importance for anuran amphibians, being an important micro-habitat for this order of amphibians.

For studies performed in the Amazon Biome we have: Santos et al. (2018), in a study in mature forest in central Amazonia, acquired estimates of biomass ( $B_{\text {wood }}$ ) of the bole wood with bark ranging between 299.60 and 29.46. tC.ha ${ }^{-1}$, with a mean of $327.8 \pm 41.9$. tC.ha ${ }^{-1}$. Saldarriaga et al. (1988), in a study on ecological succession in the Amazon region, found wood biomass ( $B_{\text {wood }}$ ) of the stem in four stands of mature forests ranging between 107 and 145. tC.ha-1.

In general it is observable that the results found for estimates of biomass (Bwood) and carbon stored 
above ground in the Amazon biome, provided higher values than this study. However the results were close to those found by Ribeiro et al. (2009) and for the studies by Silva et al. (2018) and Silva et al. (2019) all in the Atlantic Forest biome. It is therefore conclusive that the forest ecosystem of the Nova Canaã farm proved to be extremely capable in carrying out the environmental service of carbon sequestration and storage, benefiting society and the environment.

\section{CONCLUSIONS}

Through the study carried out it was possible to observe the importance of the conservation of forest fragments in the northwest of Rio de Janeiro, especially those destined to the conservation of biodiversity and the maintenance of the mesoclimate and microclimate. The diversity of the forests of the Atlantic Forest, attenuate the negative effects of climate change, as they enable the significant removal of $\mathrm{CO}_{2}$ from the atmosphere, through biomass and carbon stored in the secondary xylem.

The determination of the stored carbon (SC) by species, indicates which are the ones with the greatest potential for fixation, being a relevant indicator in the studies of forest restoration focusing on the sale of carbon credits. Among the analyzed species, Guarea guidonia was the one that stood out the most similar to the studies by Silva et al. (2018) in the municipal natural park of Curió (Paracambi/RJ).

The immobilization of $\mathrm{CO}_{2}$ by rural properties is an alternative to the use of environmental services. As carbon sequestration it is extremely important that areas such as the Nova Canaã farm be inserted in the carbon credit Market receiving support from public and private entities, such as river basin committees and carbon credit certifiers. Thus subsidizing and corroborating with projects focused on the Clean Development Mechanism (CDM) developed in these properties.

ACKNOWLEDGMENTS: To OM Consultoria Ambiental, for funding and scientific contribution. To the Brazilian Scientific Production Company (CBPC), for rereading, organizing and publishing this work. To Mr. Celio Jorge owner of Fazenda Nova Canaã and a paladin citizen focused on sustainable development in the Fluminense Northwest of Rio de Janeiro. To Doctor Alexandre Ramalho admirable and quick lawyer in the legal guidelines.

\section{REFERENCES}

ABNT. Associação Brasileira de Normas Técnicas. NBR 11941-02: Determinação da densidade básica em madeira. Rio de Janeiro: ABNT, 2003.

BRASIL. Conselho Nacional do Meio Ambiente. Resolução CONAMA n. 06, de 4 de maio de 1994. Estabelece definições e parâmetros mensuráveis para análise de sucessão ecológica da Mata Atlântica no Estado do Rio de Janeiro. Brasília: DOU, 1994.

BERGALLO, H. G.; BERGALLO, A. C.; ROCHA, H. B; ROCHA, C. F. D.. Invasion by Artocarpus heterophyllus (Moraceae) in an island in the Atlantic Forest Biome, Brazil: distribution at the landscape level, density and need for control. Journal of Coastal Conservation, v.20, n.3, p.191-198, 2016. DOI: http://doi.org/10.1007/s11852-016-0429-9
BROWN, S.; GILLESPIE, A. J. R.; LUGO, A. E.. Biomass estimation methods for tropical forests with applications to forest inventory data. Forest Science, v.35, n.4, p.881-902, 1989.

CETEC. Fundação Centro Tecnológico de Minas Gerais. Determination of Volumetric equations applicable to the sustainable management of native forests in the state of Minas Gerais, and other regions of the country. Belo Horizonte: CETEC, 1995.

FUKUDA, M.; IEHARA, T.; MATSUMOTO, M.. Carbon stock estimates for sugi and hinoki forests in Japan. Forest Ecology and Management, v.184, n.1-3, p.1-16, 2003. DOI: http://doi.org/10.1016/S0378-1127(03)00146-4 
HUSCH, B.; MILLER, C. L.; BEER, S. Forest mensuration. 3 ed. New York: J. Willey \&Sounds, 1982.

IBAMA. Instituto Brasileiro do Meio Ambiente e dos Recursos Naturais Renováveis. Flora. Brasília: IBAMA, 2016.

HENRY, M.; PICARD, N.; TROTTA, C.; MANLAY, R. J.; VALENTINI, R.; BERNOUX, M.; SAINT-ANDRÉ, L.. Estimating tree biomass of sub-Saharan African forests: a review of available allometric equations. Silva Fennica, v.45, n.3B, p.477-569, 2011.

LORENZI, H. J.. Brazilian trees: Book I. 5 ed. Nova Odessa: Publisher Plantarum, 2014.

RIBEIRO, S. C.; MAPELI, A. G.; SOARES, C. P. B.; MARTINS, S V.; SOUZA, A. L.; NARDELLI, A. M. B.. Quantification of Estimation of biomass and carbon stock in a mature forest in the city of Viçosa, Minas Gerais. Revista árvore, v.33, n.5, p.917-926, 2009. DOI: http://doi.org/10.1590/\$010067622009000500014

SALDARRIAGA, J. G.; WEST, D. C.; THARP, M. L.; UHL, C.. Long-term chronosequence of forest succession in the upper Rio Negro of Colombia and Venezuela. Journal of Ecology, v.76, p.938-958, 1988.

SANTOS, F. G.; CAMARGO, P. B.; OLIVEIRA JUNIOR, R. C.. Estoque e dinâmica de biomassa arbórea em floresta ombrófila densa na flona tapajós: amazônia oriental. Ciência Florestal, v.28, p.1049, 2018.

SILVA, C. V. V.; ALMEIDA, J. R.; SILVA, C. E.; CARVALHO, L. O.; SILVA, C. D.; RIGUEIRAL, L. H. G.; PAULA, R. G.. Structure and floristic survey of a forest fragment in the Billings Reservoir, São Paulo. Revista Ibero Americana de Ciências Ambientais, v.9, n.7, p.1-11, 2018. DOI: http://doi.org/10.6008/CBPC2179-6858.2018.007.0001

SILVA, C.V.V.; SILVA, K. A.; ABREU, L. S.; SILVA, E. R.; ALMEIDA, J. R.. Estimation of the Carbon Biomass Stored in the Forest Ecosystem of the Billings Reservoir-SP. Revista Internacional de Ciências, v.9, p.34-53, 2019.
SILVA, C. V. V.; SILVA, L. M. S.; TAVARES, R.; SILVA, W. S. Utilização de Características Fitossociológicas e Bioindicadoras no Monitoramento Ambiental e Avaliação de Impacto Nas Bacias do Rio Guandu/RJ. In: JORNADA FLUMINENSE DE BOTÂNICA, 32. Anais. Niterói, 2013.

SILVA, L. C.; ARAUJO, E. J. G.; CURTO, R. A.; NASCIMENTO, A. M.; ATAIDE, D. H. S.; MORAIS, V. A.. Estoques de biomassa e carbono em unidade de conservação no bioma Mata Atlântica. BIOFIX Scientific Journal, v.3, n.2, p.243-251, 2018.

SILVA, C. V. V.; ABREU, L. A. S.; LEAL, J. C.. Uso da Volumetria na Avaliação da Concentração de Carbono da APA GuanduJacatirão, Queimados/RJ. In: CONGRESSO NACIONAL DO MEIO AMBIENTE, 14. Anais. Poços de Caldas, 2017.

SILVA, C. V. V.; TOMAS JUNIOR, O. A.; CARVALHO, L. O.; NOVAES, E. B.. Biomassa e Estimativa de Carbono Estocado em Ecossistema Florestal da Represa Billings/SP. In: CONGRESSO NACIONAL DO MEIO AMBIENTE, 15. Anais. Poços de Caldas, 2018.

SILVA, C. V. V.; ABREU, L. A. S.; LEA, J. C.; LOUREIRO, A.; GROETARS, A.. Inventário Florístico da APA Guandu-Jacatirão o uso da Resolução CONAMA n.04, de Maio de 1994 - RJ, para Análise de Parâmetros da Qualidade Ambiental. In: CONGRESSO NACIONAL DO MEIO AMBIENTE, 14. Anais. Poços de Caldas, 2017.

SOFFIATI NETTO, A. A.. Brief eco-historical study of human use of seasonal forests in the north-northwestern regions of Rio de Janeiro State in the colonial and republican periods. Revista Vértices, v.13, p.7-30, 2011. DOI: http://doi.org/10.5935/1809-2667.20110011

SOS MATA ATLÂNTICA. Atlas of forest remnants of the Mata Atlântica period 2015: final report. Rio de Janeiro: The SOS, 2015.

TORRES, C. M. M. E.; JACOVINE, L. A. G.; SOARES, C. P. B.; NETO, S. N. O.; SANTOS, R. D.; NETO, F. C.. Quantificação de Biomassa e Estocagem de Carbono em uma Floresta Estacional Semidecidual, no Parque Tecnológico de Viçosa, MG. Revista Árvore, Viçosa, v.37, n.4, 2013.

A CBPC - Companhia Brasileira de Produção Científica (CNPJ: 11.221.422/0001-03) detém os direitos materiais desta publicação. Os direitos referem-se à publicação do trabalho em qualquer parte do mundo, incluindo os direitos às renovações, expansões e disseminações da contribuição, bem como outros direitos subsidiários. Todos os trabalhos publicados eletronicamente poderão posteriormente ser publicados em coletâneas impressas sob coordenação da Sapientiae Publishing, da Companhia Brasileira de Produção Científica e seus parceiros autorizados. Os (as) autores (as) preservam os direitos autorais, mas não têm permissão para a publicação da contribuição em outro meio, impresso ou digital, em português ou em tradução. 